\title{
Response of an abyssal macrofaunal community to a phytodetrital pulse
}

\author{
A. K. Sweetman ${ }^{1,3, *}$, U. Witte ${ }^{2}$ \\ ${ }^{1}$ Max-Planck-Institut für Marine Mikrobiologie, Celsiusstrasse 1, 28359 Bremen, Germany \\ ${ }^{2}$ Oceanlab, University of Aberdeen, Newburgh, Aberdeenshire AB41 6AA, UK \\ ${ }^{3}$ Present address: Department of Oceanography, University of Hawaii at Manoa, 1000 Pope Road, Honolulu, \\ Hawaii 96822, USA
}

\begin{abstract}
The majority of deep-sea benthic communities rely on particulate organic matter (POM) sinking from the euphotic zone for energy, much of which is delivered in pulsed events. But we know little about abyssal plain macrofaunal communities, their response to such events or their role in deep-sea carbon-cycling. In this study, we examined the composition of the macrofaunal community at Station M in the deep NE Pacific and assessed its short-term response to a simulated OM pulse in two $36 \mathrm{~h}$ in situ enrichment experiments. In each experiment, $1.2 \mathrm{~g} \mathrm{C} \mathrm{m}^{-2}$ of ${ }^{13} \mathrm{C}$-labelled Skeletonema costatum was deposited onto the seafloor using a benthic chamber lander. Macrofaunal abundance and biomass were significantly higher at 0 to $5 \mathrm{~cm}$ depth compared to 5 to $10 \mathrm{~cm}$, and were dominated by the Nematoda and Crustacea, respectively. Twenty-five percent of the macrofauna specimens showed ${ }^{13} \mathrm{C}$ signatures indicative of label ingestion, but specific uptake $\left(\Delta \delta^{13} \mathrm{C}\right)$ and $\mathrm{C}$-turnover rates varied strongly between and within taxa. Two organisms, a single cumacean from 1 chamber and a paraonid polychaete from the second chamber, were responsible for the majority of C-uptake and had ingested up to $2.3 \%$ of their body weight in C. Macrofaunal C-turnover was much lower than recorded in the abyssal NE Atlantic, which is most likely due to differences in the timing of the experiments relative to the spring/summer bloom, different experimental durations and disparities in macrofaunal community structure. These results emphasize the degree of plasticity inherent in the macrofaunal response to a food pulse and stress the need for comprehensive in situ investigations to further our understanding of deep-sea benthic ecosystem functioning.
\end{abstract}

KEY WORDS: Abyssal plain $\cdot$ Northeast Pacific $\cdot$ Deep sea $\cdot$ Pulse-chase experiments $\cdot \delta^{13} \mathrm{C} \cdot \delta^{15} \mathrm{~N}$. Natural isotopic signatures $\cdot$ Benthic carbon remineralisation $\cdot$ Macrofauna

\section{INTRODUCTION}

Prior to the early 1980s, it was thought that the majority of deep-sea communities derived their energy from a constant 'drizzle' of relatively refractory organic matter. However, within the last $25 \mathrm{yr}$ it has become apparent that this 'rain' of particulate organic matter (POM) can be punctuated by large, episodic, pulses of labile POM to the seafloor (Deuser \& Ross 1980, Billett et al. 1983). It is from these downpours of organic matter that the majority of deep-sea communities obtain most of their energy (Gooday 1988, Graf 1989, Pfannkuche 1993), with the exception of reducing systems. Recent studies have additionally shown from both time-lapse camera systems and sediment trap moorings that large inter-annual variations in the supply of POM to the deep-seafloor do exist, and are regular features of this environment (Smith et al. 1994, 2001, 2006, Baldwin et al. 1998). Furthermore, rapid responses to POM input by a number of deep-sea benthic taxonomic groups from microbes (Pfannkuche 1993, Lochte \& Turley 1988) and protozoa (Gooday 1988, Drazen et al. 1998), to megafauna (Smith et al. 1994, Lauerman et al. 1997, Bett et al. 2001) have been identified. 
Macrofaunal communities can provide helpful information about the quality and quantity of POM arriving at the seafloor, and can assist in predicting its overall fate within the sediment. For example, the vast majority of macrofauna found at abyssal depths are considered deposit feeders (Hessler \& Jumars 1974) that, through bioturbation and feeding, considerably re-work sediment, thus affecting the early diagenesis of recently deposited POM (Levin et al. 1997). However, owing to the inherent costs and difficulties associated with sampling deep-sea environments, especially abyssal habitats, detailed knowledge of deep-sea macrofaunal trophic interactions, including their access to and ingestion rates of POM, have yet to be established.

Conventional analysis using gut contents to infer food-web structure in the deep sea has proved successful for megafauna (Lauerman et al. 1997), but is almost impossible to carry out on small-sized biota, such as macrofauna. Recently, the establishment of stable isotope techniques has created numerous opportunities for studying macrofaunal trophic interactions (Iken et al. 2001), and the development of the pulse-chase approach has allowed direct quantification of $\mathrm{C}$ flow through benthic food webs (Middelburg et al. 2000, Witte et al. 2003a). In in situ pulse-chase experiments at abyssal depths, Witte et al. (2003a) found during a $60 \mathrm{~h}$ experiment that among bacteria, Foraminifera, Nematoda and macrofauna, macrofauna responded to and processed $\mathrm{C}$ faster when incubated with fresh phytodetritus. Witte et al. (2003b) reported a similar reaction by infaunal macrofauna from the deep Norwegian Sognefjord (1265 m) during a 3D experiment. Furthermore, a detailed study by Aberle \& Witte (2003) revealed that, of the dominant taxa, crustaceans were of minor importance in $\mathrm{C}$ cycling in the abyssal NE Atlantic, but cirratulid and spionid polychaetes played a leading role in re-working freshly deposited material, in a similar manner to the maldanid and paraonid polychaetes on the Carolina continental slope (Levin et al. 1997, 1999).

The coupling of pelagic and benthic processes has been studied repeatedly since 1989 in the abyssal NE Pacific at Station M (Smith \& Druffel 1998); however, detailed information on macrofaunal community structure and trophic interactions is lacking for this site and for the abyssal Pacific in general. This study therefore examines macrofaunal community composition at Station $\mathrm{M}$ and explores food web structure using natural $\mathrm{C}$ and $\mathrm{N}$ isotopic signatures. We also describe for the first time the short-term response of an abyssal Pacific macrofaunal community to a simulated phytodetritus pulse. We present in situ data from 2 replicate enrichment experiments carried out at Station M using a benthic chamber lander in October 2004. Diatoms, labeled with ${ }^{13} \mathrm{C}$, were incubated for a period of $36 \mathrm{~h}$ over a known area of seafloor and uptake of labelled $\mathrm{C}$ into the metazoan macrofauna was subsequently measured. We specifically focused our attention on the polychaetes, since this group comprises a number of dominant functional groups whose diversity is known to affect biogeochemical fluxes (e.g. $\mathrm{PO}_{4}{ }^{3-}$ and $\mathrm{O}_{2}$ ), profiles (e.g. $\mathrm{O}_{2}$ and $\mathrm{pH}$ ), and transport rates in addition to rates of organic matter remineralisation (Levin et al. 1997, 1999, Aberle \& Witte 2003, Waldbusser et al. 2004, Waldbusser \& Marinelli 2006).

\section{MATERIALS AND METHODS}

In late October 2004, during cruise PULSE 45 of the RV 'New Horizon,' in situ pulse-chase experiments were carried out at Station M $\left(34^{\circ} 50^{\prime} \mathrm{N}, 123^{\circ} 00^{\prime} \mathrm{W}\right.$, ca. $4100 \mathrm{~m}$ water depth, Fig. 1), located approximately 220 nautical miles west of Point Conception, California, at the base of the Monterey Deep-Sea Fan. The seafloor at Station $M$ is characterised by silty-clay sediments with an organic $\mathrm{C}$ content of approximately $17 \mathrm{mg} \mathrm{C} \mathrm{g}^{-1}$ and possesses little topographical relief $\left(<100 \mathrm{~m}\right.$ over $1600 \mathrm{~km}^{2}$ ) (Smith et al. 1994, 2001, Smith \& Druffel 1998).

A non-axenic clone of the diatom Skeletonema costatum (Bacillariophyta) was used as a labelled food source in our experiments. This diatom species was chosen as a suitable food source since it occurs within the vicinity of, and has been sampled in sediment traps moored above, the seafloor at Station M (Venrick 1998, Beaulieu \& Smith 1998). Algae were cultured in an artificial seawater medium modified with $\mathrm{F} / 2$ (Grasshoff et al. 1999). The culture medium was amended by replacing $25 \%$ of ${ }^{12} \mathrm{C}$ bicarbonate with $\mathrm{NaH}^{13} \mathrm{CO}_{3}$. Diatoms were cultured for 3 wk at $15^{\circ} \mathrm{C}$ under a 16:8 h light:dark cycle and harvested. To harvest, inoculums were concentrated by centrifugation $(404 \times g, 5 \mathrm{~min})$, washed 4 times in a isotonic solution to remove excess labelled bicarbonate, and freeze dried. Algae possessed a ${ }^{13} \mathrm{C}$ content of $7.9 \pm$ 0.4 atom $\%(n=6)$ and a C:N ratio of $9 \pm 1(n=6)$. Comparatively similar $\mathrm{C}: \mathrm{N}$ ratios of added algae to seafloor phytodetrital aggregates $(\mathrm{C}: \mathrm{N}=11)$ sampled in September 1994 at Station M (Smith et al. 1998) suggest that the POM used was representative of natural phytodetritus entering the benthic boundary layer (BBL) in autumn.

Macrofaunal community structure was assessed from 3 multiple corer (MUC) and 3 benthic chamber sediment samples. Macrofauna from the MUC cores were additionally used for natural or 'background' $\delta^{13} \mathrm{C}$ and $\delta^{15} \mathrm{~N}$ measurements. MUC cores were sampled at a depth of $4062 \mathrm{~m}$, and processed in a cold-room once 


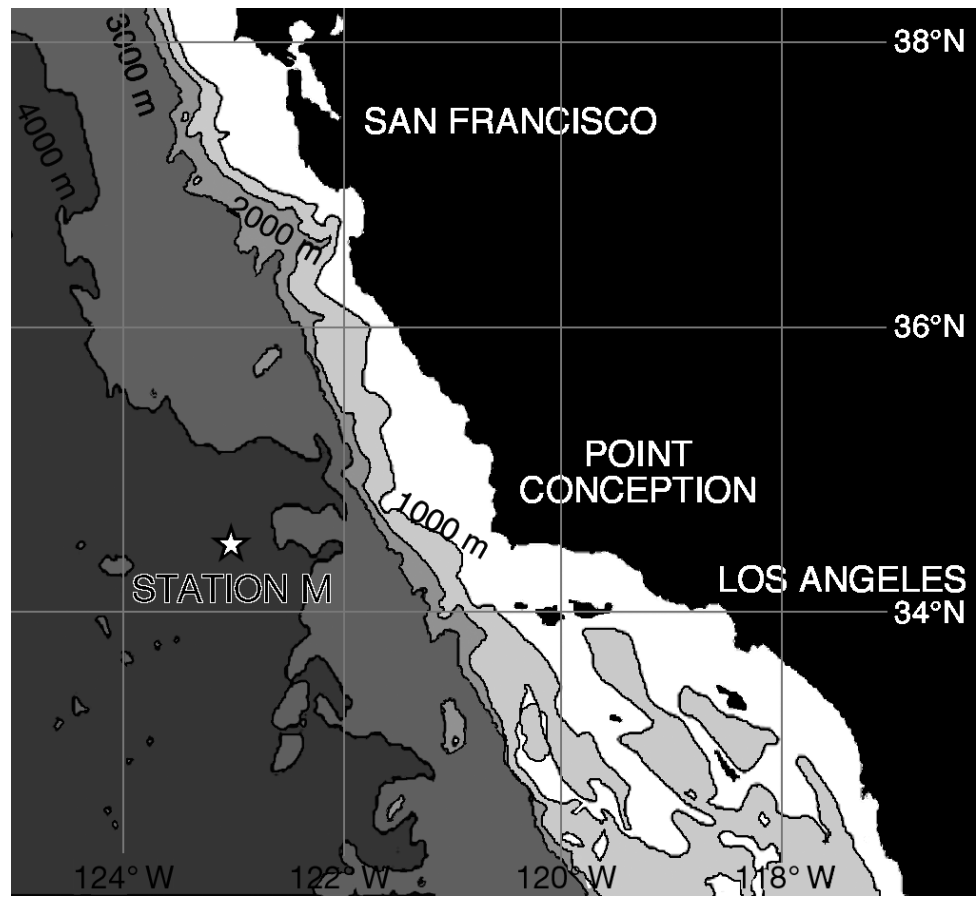

Fig. 1. Station M in the NE Pacific turned on and the chamber waters gently mixed (without creating sediment resuspension) for the duration of the $36 \mathrm{~h}$ in situ incubation. After $36 \mathrm{~h}$, the lander was recalled to the surface, where it was discovered that the algal injector in the third chamber (Chamber 1) failed to work in concert with the other two (Chambers 2 \& 3) and only fired during the recovery of the lander, thus contaminating this 'control' chamber. As such, Chamber 1 was only used for macrofaunal abundance and biomass data. Once onboard, half of the enclosed sediment $\left(200 \mathrm{~cm}^{2}\right)$ in each of the 3 chambers was sectioned and processed as above. In an effort to gather greater numbers of animals for C-uptake measurements, an additional core $(6 \mathrm{~cm} \varnothing)$, initially sectioned and preserved unsieved for Foraminifera ( 0 to 2 and 2 to $5 \mathrm{~cm}$ ), was taken from the second half of each chamber and later sieved in the laboratory for metazoan macrofauna $(>250 \mu \mathrm{m})$. Sieved animals from both the $28.3 \mathrm{~cm}^{2}$ core and $200 \mathrm{~cm}^{2}$ sediment samples from 0 to 2 and 2 to $5 \mathrm{~cm}$ were then pooled.

In the laboratory, sieved samples were picked for macrofauna $(>250 \mu \mathrm{m})$ in cooled artificial seawater (salinity 35) under a binocular microscope and transferred to $4 \%$ buffered formaldehyde solution. To derive information from macrofaunal natural isotopic signatures about potential food sources at Station $M$, $\delta^{13} \mathrm{C}$ signatures from 'background' macrofauna were corrected for formaldehyde preservation effects by adding $1 \%$ to each $\delta^{13} \mathrm{C}$ value (Kaehler \& Pakhomov 2001, Sarakinos et al. 2002). Only 13 of the 25 macrofaunal samples measured for background $\mathrm{C}$ and $\mathrm{N}$ signatures possessed enough biomass for natural $\delta^{15} \mathrm{~N}$ measurements. Preservation effects on stable isotope signatures were considered to be negligible ( 0.5 to $1 \%$, L. Levin \& C. R. Smith pers. comm.) compared to tracer uptake; thus, no corrections were applied to 'background' or 'enriched' signatures when calculating specific uptake of ${ }^{13} \mathrm{C}$ and $\mathrm{C}$-uptake. Separate picking utensils were used for background and labelled samples to avoid contamination of stable isotopes. Organisms were identified to major taxon, with polychaetes being identified to family or lowest taxonomic level possible. Crustacea were identified to class or order. Single organisms were cleaned of attached organic debris in cooled, clean artificial seawater (salinity 35), placed in silver caps and dried at 35 to $40^{\circ} \mathrm{C}$ for a period of $2 \mathrm{wk}$. Calcareous shelled organisms were decalcified with $2 \mathrm{M} \mathrm{HCl}$ in double boated

silver caps and dried as above. In order to obtain algal injection, stirrers were switched off for $1 \mathrm{~h}$ to allow the labelled algae to sink. Stirrers were then 
sufficient biomass for isotope measurements, some individual organisms (see Table 1) were combined as in Aberle \& Witte (2003) and Kamp \& Witte (2005). Prior to isotopic analysis, all organisms were weighed on an electronic microbalance (Sartorius) for biomass determinations (mg dry weight).

From the second half of each benthic chamber, a $6 \mathrm{~cm}(\varnothing)$ core was taken for determination of total organic (TO) ${ }^{13} \mathrm{C}$ signatures of the sediment $\left(\Delta \delta \mathrm{TO}^{13} \mathrm{C}\right)$. Each core was extruded at $1 \mathrm{~cm}$ intervals from 0 to $5 \mathrm{~cm}$, at a $2 \mathrm{~cm}$ interval from 5 to $7 \mathrm{~cm}$, and at a $3 \mathrm{~cm}$ interval from 7 to $10 \mathrm{~cm}$. Sectioned sediment cakes were placed in brown glass bottles and immediately frozen at $-20^{\circ} \mathrm{C}$. Background sediment samples were collected from a fourth MUC core $(10 \mathrm{~cm} \varnothing ; 4062 \mathrm{~m}$ depth) and processed in the same way. Upon return to the laboratory, each cutlet was freeze-dried for $4 \mathrm{~d}$ and homogenized using a pestle and mortar. From each homogenized horizon, approximately 50 to $100 \mathrm{mg}$ of freeze-dried sediment was transferred to a precombusted glass tube $\left(550^{\circ} \mathrm{C}\right.$ for $\left.5 \mathrm{~h}\right)$ and decalcified overnight with $10 \% \mathrm{HCl}$. Decalcified sediment was vigorously washed 4 times with Milli-Q water, concentrated by centrifugation and dried at $50^{\circ} \mathrm{C}$ for $3 \mathrm{~d}$. Approximately $30 \mathrm{mg}$ of pre-acidified sediment was then transferred to tin caps for isotope ratio mass spectrometry (IRMS) analysis.

The isotopic ratios of the macrofaunal organisms were measured using a Finnigan Delta plus XP (Thermo) Isotope Ratio Mass Spectrometer at MPI Bremen (reproducibility: $\delta^{13} \mathrm{C}=0.2 \%, \delta^{15} \mathrm{~N}=0.8 \%$ ) and those of the sediment samples analysed using a Europa Integra (enriched isotopes) and Hydra 20/20 (natural isotopes) IRMS at UC Davis (reproducibility: $\delta^{13} \mathrm{C}=0.02 \%$ o, $\delta^{15} \mathrm{~N}=0.06 \%$ o). Macrofaunal C-isotopic ratios $\left({ }^{13} \mathrm{C} /{ }^{12} \mathrm{C}\right)$ were measured against a PDB standard and are expressed as delta notation $\left(\delta^{13} \mathrm{C}\right)$ as relative difference between sample and standard: $\delta^{13} \mathrm{C}(\%)=$ $\left[\left({ }^{13} \mathrm{C} /{ }^{12} \mathrm{C}_{\text {sample }}\right) /\left({ }^{13} \mathrm{C} /{ }^{12} \mathrm{C}_{\text {standard }}\right)-1\right] \times 10^{3}$. Specific uptake of ${ }^{13} \mathrm{C}$ by macrofaunal organisms was calculated as excess (above background) and is expressed in $\Delta \delta^{13} \mathrm{C}$ notation: $\Delta \delta^{13} \mathrm{C}=\delta^{13} \mathrm{C}_{\text {sample }}-$

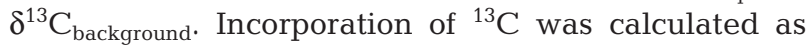
the product of the excess atom $\%{ }^{13} \mathrm{C}$ (difference in atom $\%{ }^{13} \mathrm{C}$ between sample and background) and $\mathrm{C}$ content (expressed as unit weight): ${ }^{13} \mathrm{C}$ incorporation (unit wt $\left.{ }^{13} \mathrm{C}\right)=\left(\right.$ atom $\%{ }^{13} \mathrm{C}_{\text {sample }}-$ atom $\left.\%{ }^{13} \mathrm{C}_{\text {background }}\right) \times$ (unit wt $\mathrm{C}$ of organism). ${ }^{13} \mathrm{C}$ incorporation was then adjusted to account for the ${ }^{13} \mathrm{C}$ algal labelling, yielding total $\mathrm{C}$ uptake: $\mathrm{C}$ uptake (unit wt $\mathrm{C}$ ) $={ }^{13} \mathrm{C}$ incorporation/7.9 atom \%. C-uptake was then normalized to $24 \mathrm{~h}$ to give total C-turnover. Specific labelling $\left(\Delta \delta \mathrm{TO}^{13} \mathrm{C}\right)$ of sediment was measured relative to a PDB standard and expressed as excess above background as $\Delta \delta \mathrm{TO}^{13} \mathrm{C}=\delta \mathrm{TO}^{13} \mathrm{C}_{\text {sample }}-\delta \mathrm{TO}^{13} \mathrm{C}_{\text {background sediment }}$.

\section{RESULTS}

\section{Macrofaunal abundance and biomass}

Total macrofaunal density was $6165 \pm 3751$ individuals (ind.) $\mathrm{m}^{-2} / 2462 \pm 396$ ind. $\mathrm{m}^{-2}(\mathrm{SD}, \mathrm{n}=4$, including/excluding nematodes). Total biomass was $509 \pm 226 \mathrm{mg}$ dry wt m ${ }^{-2} / 485 \pm 227 \mathrm{mg}$ dry wt m ${ }^{-2}$ (SD, $\mathrm{n}=4$, including/excluding nematodes). The top $2 \mathrm{~cm}$ of sediment at Station $\mathrm{M}$ comprised the greatest concentration ( $53 \%$ ) of macrofauna with $4350 \pm 2270$ ind. $\mathrm{m}^{-2}$ ( $\mathrm{SD}, \mathrm{n}=6$, including nematodes, Fig. 2a). Macrofaunal abundance decreased below $2 \mathrm{~cm}$ sediment depth with $42 \%\left(3419 \pm 1986\right.$ ind. $\mathrm{m}^{-2}, \mathrm{SD}, \mathrm{n}=6$, including nematodes) and $5 \%$ (432 \pm 390 ind. $\mathrm{m}^{-2}, \mathrm{SD}, \mathrm{n}=4$, including nematodes) found within the 2 to $5 \mathrm{~cm}$ and 5 to $10 \mathrm{~cm}$ horizons, respectively (Fig. 2a). Significantly higher abundances were found in the 0 to $5 \mathrm{~cm}$ horizon compared to the 5 to $10 \mathrm{~cm}$ layer $\left(t\right.$-test, $t_{6}=3.132, \mathrm{p}=$ 0.020) when adjusted for multiple testing (Holm 1979). Maximum biomass values were observed at 0 to $2 \mathrm{~cm}$ (Fig. 2b). After correcting for multiple testing (Holm 1979), biomass values were significantly different
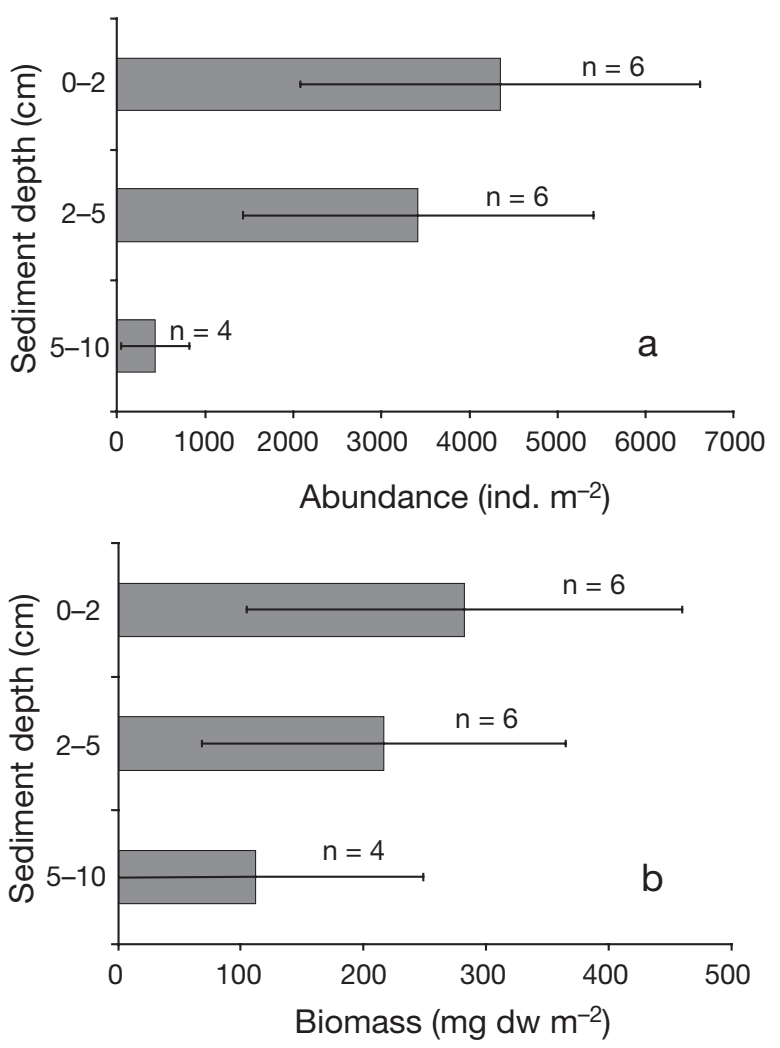

Fig. 2. Vertical distribution of (a) total macrofaunal abundance and (b) biomass within the sediment column (0 to $10 \mathrm{~cm})$ at Station $\mathrm{M}( \pm 1 \mathrm{SD}) . \mathrm{n}=6$ denotes samples from 3 benthic chambers and 3 MUC cores; $\mathrm{n}=4$ denotes samples from 3 benthic chambers and 1 MUC core 
between the 0 to 5 and 5 to $10 \mathrm{~cm}$ depths ( $t$-test, $t_{6}=$ $2.998, \mathrm{p}=0.024)$. The majority of organisms (95\%) and biomass (82\%) were found within the top $5 \mathrm{~cm}$ (Fig. 2). Because the presence of a single large opheliid polychaete (1172 mg dry wt $\mathrm{m}^{-2}$ ) in Chamber 1 drastically altered biomass estimates, this animal was removed from further analysis. Macrofaunal community composition is given in Fig. 3. Altogether, 10 major macrofaunal taxa were found at Station $M$. The Nematoda contributed $60 \%$ to macrofaunal abundance, but only $6 \%$ to overall biomass. The Crustacea were the second most abundant taxon (23\%) and made up $43 \%$ of the biomass, followed by the Polychaeta, which contributed $8 \%$ to overall abundance and $29 \%$ to biomass. Although the Harpacticoida were the most abundant (56\%) crustacean group, the Ostracoda made up for most of the crustacean biomass (40\%). Members of the family Paraonidae (20\%) and Pilargidae (15\%) were the most common polychaete families found, but the Capitellidae contributed by far the most biomass (65\%), followed by the Paraonidae $(10 \%)$.

\section{Natural isotopic signatures and ${ }^{13} \mathrm{C}$ labelling experiments}

Natural $\delta^{13} \mathrm{C}$ and $\delta^{15} \mathrm{~N}$ signatures are summarized in Fig. 4. Delta ${ }^{13} \mathrm{C}$ signatures showed negative values and ranged from -15.8 to $-27.8 \%$. The highest and lowest $\delta^{13} \mathrm{C}$ signatures were measured for an ostracod $(-15.8 \%)$ and a syllid polychaete $(-27.8 \%)$, respectively. Natural $\delta^{13} \mathrm{C}$ signatures of polychaetes $(\mathrm{n}=14)$ and crustaceans $(\mathrm{n}=7$ ) were $-20.2 \pm 2.7 \%$ (SD) and $-19.1 \pm 2.1 \%$ o (SD), respectively. Delta ${ }^{13} \mathrm{C}$ and ${ }^{15} \mathrm{~N}$ signatures of surface $\left(\delta^{13} \mathrm{C}=-19.5 \%, \mathrm{n}=2, \delta^{15} \mathrm{~N}=16.5 \%\right.$, $\mathrm{n}=2$ ) and sub-surface deposit feeding polychaetes $\left(\delta^{13} \mathrm{C}=-19.6 \pm 1.1 \%\right.$, $\mathrm{SD}, \mathrm{n}=7, \delta^{15} \mathrm{~N}=17.8 \pm 1.2 \%$, SD， $\mathrm{n}=4$ ) showed little variation amongst functional groups. Carnivorous polychaete families were on average slightly lighter, but comparable $(-20.8 \%$, $\mathrm{n}=4)$, although they displayed far more variability (range: -17.2 to $-27.8 \%$ ) in ${ }^{13} \mathrm{C}$ over deposit feeding polychaetes. Mean $\delta^{15} \mathrm{~N}$ signatures of carnivorous (18.1\%, $\mathrm{n}=2$ ) vs. sub-surface deposit feeding polychaetes were approximately identical. Amongst the polychaetes, a pilargid of the species Ancistrosyllis homata showed the highest $\delta^{13} \mathrm{C}$ signature $(-17.2 \%$ ), and a syllid polychaete of the genus Brania sp. possessed the lowest $\left(-27.8 \%\right.$ ), whilst $\delta^{15} \mathrm{~N}$ signatures ranged from $15.6 \%$ for the Ampharetidae to $19.4 \%$ for the Opheliidae. Natural $\delta^{13} \mathrm{C}$ measurements for the crustaceans ranged from $-15.8 \%$ (Ostracoda) to $-21.4 \%$ (Tanaidacea), and $\delta^{15} \mathrm{~N}$ signatures for the harpacticoida and isopoda were $14.3 \%$ and $15.7 \%$, respectively. We did not observe background $\delta^{13} \mathrm{C}$ signatures
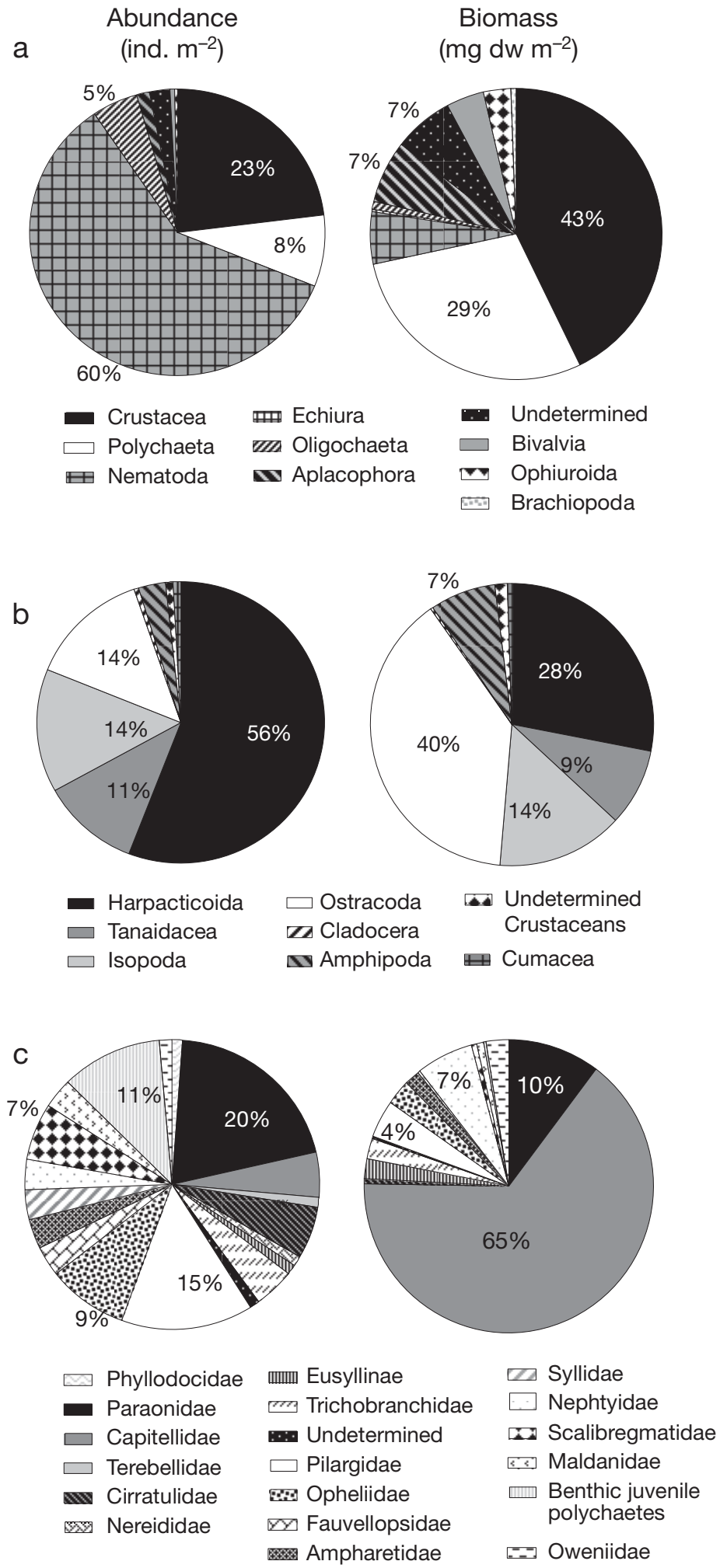

Fig. 3. Relative abundance (individuals $\mathrm{m}^{-2}$ ) and biomass (mg dry wt $\mathrm{m}^{-2}$ ) of (a) major macrofaunal taxa (including nematodes), (b) major crustacean taxa, and (c) major polychaete families, at Station M (all data from 3 benthic chambers, 3 MUC cores) 


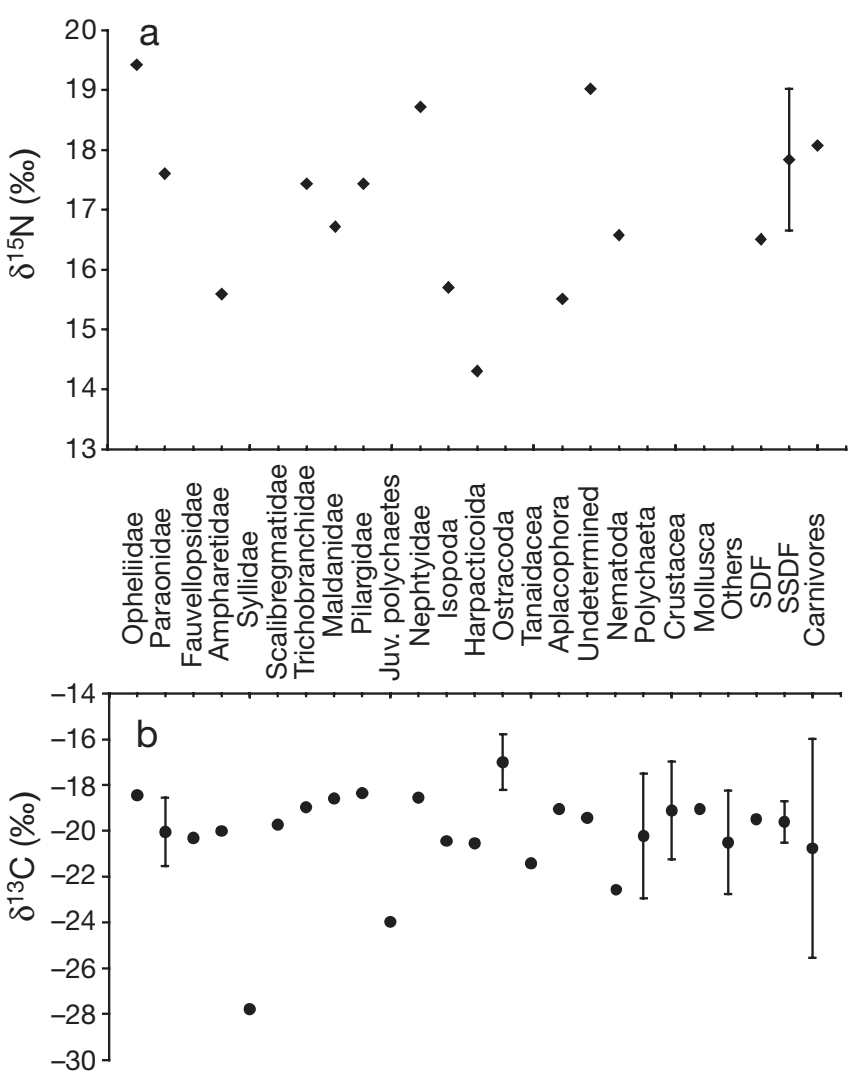

Fig. 4. Natural (a) $\delta^{15} \mathrm{~N}$ and (b) $\delta^{13} \mathrm{C}$ signatures of MUCcollected macrofauna taxa at Station M. Groups 'Polychaeta,' 'Crustacea,' 'Mollusca,' 'SDF,' 'SSDF' (surface- and subsurface deposit feeders, respectively) and 'Carnivores' denote mean of natural isotopic signatures of all polychaetes, crustaceans, molluscs, surface deposit-feeding, sub-surface deposit-feeding and carnivorous polychaetes, respectively. 'Others' refers to mean of $\delta^{13} \mathrm{C}$ signatures of undetermined taxa and nematodes. Feeding guilds of polychaetes were determined from Fauchald \& Jumars (1979). Bars denote \pm 1 SD

higher than $-15.8 \%$. Thus, in our enrichment experiments we considered signatures $>-14 \%$ as evidence of incorporation of ${ }^{13} \mathrm{C}$ from our labelled algae (Aberle \& Witte 2003). Delta ${ }^{13} \mathrm{C}$ and $\delta^{15} \mathrm{~N}$ signatures of decalcified sediment at Station $M$ were $-22 \pm 0.1 \%$ o $(S D, n=7)$ and $9 \pm 0.1 \%$ o $(\mathrm{SD}, \mathrm{n}=7$ ), respectively.

The isotopic signatures of macrofaunal organisms retrieved from experimental Chambers $2 \& 3$ are shown in Table 1. A number of macrofaunal organisms rapidly incorporated the ${ }^{13} \mathrm{C}$-labelled phytodetritus with $37 \%$ (Chamber 2) and 13\% (Chamber 3) of the macrofauna showing $\delta^{13} \mathrm{C}$ signatures indicative of phytodetritus ingestion after $36 \mathrm{~h}$ (Table 1). Enrichment was modest in most organisms with only 3 individuals, a cumacean $\left(\Delta \delta^{13} \mathrm{C}=127 \%\right.$ ) from Chamber 2 , and an isopod $\left(\Delta \delta^{13} \mathrm{C}=\right.$ $295 \%$ ) and paraonid polychaete $\left(\Delta \delta^{13} \mathrm{C}=165 \%\right)$ from Chamber 3 , showing $\Delta \delta^{13} \mathrm{C}$ signatures greater than
$100 \%$. At the same time, a large degree of variation was observed in enrichment between related taxa within and between each chamber. For example, a single paraonid polychaete from Chamber 3 showed a $\Delta \delta^{13} \mathrm{C}$ signature of $165 \%$, whilst additional paraonids in Chamber 3 possessed $\delta^{13} \mathrm{C}$ signatures of $<-14 \%$. Similar patterns were also seen amongst the paraonids in Chamber 2 and the isopods in Chamber 3. Highest enrichment occurred in the top $5 \mathrm{~cm}$ of sediment (Fig. 5).

C-turnover rates are shown in Table 1 . Mean metazoan macrofaunal C-uptake was $3.4 \times 10^{-3} \%$ of the $\mathrm{C}$ added. Highest turnover rates were found at 0 to $2 \mathrm{~cm}$ where $96 \%$ (Chamber 2) and $70 \%$ (Chamber 3 ) of the $\mathrm{C}$ was processed. However, there was an order of magnitude difference in C-turnover between Chambers 2 and 3. Counting the 2 amphipods in Chamber 2, $1.7 \%$ (Chamber 2) and 3.1\% (Chamber 3) of the combined biomass (C) measured by IRMS analysis were directly involved in $\mathrm{C}$-uptake. Profiles of sedimentary $\Delta \delta \mathrm{TO}^{13} \mathrm{C}$ are shown in Fig. 6.

\section{DISCUSSION}

Metazoan macrofaunal abundance decreases exponentially with increasing water depth (Flach \& Heip 1996, Cosson et al. 1997). Macrofaunal abundance was similar to macrofaunal densities observed in previous investigations at Station M (Drazen et al. 1998, mesh size $300 \mu \mathrm{m}$ ), and higher than those observed at the Porcupine Abyssal Plain (PAP) (Aberle \& Witte 2003), the Goban Spur (Flach \& Heip 1996), and the southern Arabian Sea (Witte 2000). Previous investigations have noted a linear relationship between organic carbon flux and macrofaunal density (e.g. Cosson et al. 1997). Higher particulate organic carbon (POC) fluxes to the seafloor at Station M $\left(\sim 2.4 \mathrm{~g} \mathrm{C} \mathrm{m}^{-2} \mathrm{yr}^{-1}\right.$, Baldwin et al. 1998) than those found at the PAP $\left(\sim 1.3 \mathrm{~g} \mathrm{C} \mathrm{m}^{-2} \mathrm{yr}^{-1}\right.$, Lampitt et al. 2001) and in the southern Arabian Sea ( 1.3 $\mathrm{g} \mathrm{C} \mathrm{m}^{-2} \mathrm{yr}^{-1}$, Honjo et al. 1999), probably account for the higher densities we observed at Station $\mathrm{M}$. Assuming an annual POC flux of $2.4 \mathrm{~g} \mathrm{C} \mathrm{m}^{-2} \mathrm{yr}^{-1}$ at Station M (Baldwin et al. 1998), our mean macrofaunal abundance estimates fit well into the regression published by Cosson et al. (1997).

The majority of metazoan macrofauna density and biomass was found in the top-most $5 \mathrm{~cm}$, thus adhering to profiles observed in previously studied continental slope (Blake 1994, Blair et al. 1996) and abyssal habitats, including Station M (Drazen et al. 1998) and the PAP (Aberle \& Witte 2003). Metazoan macrofaunal biomass profiles with depth were similar to profiles of macrofaunal abundance and were comparable to previous abyssal studies undertaken by Drazen et al. (1998) and Aberle \& Witte (2003). The standard 


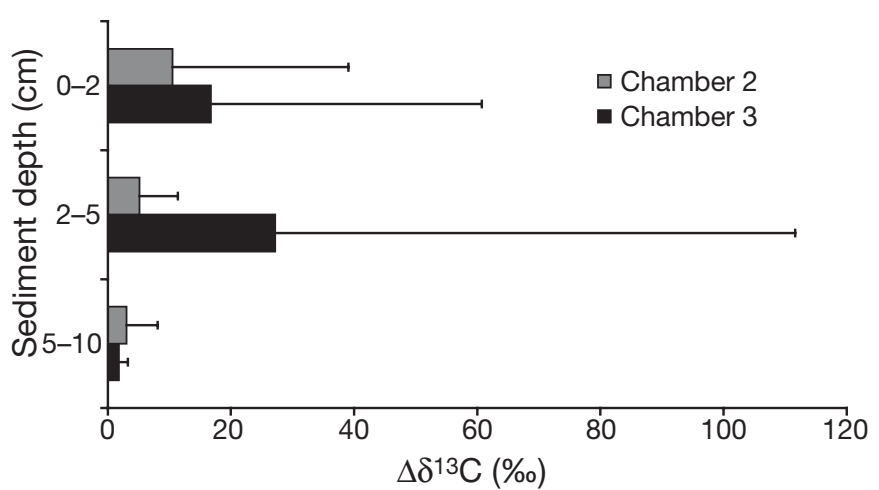

Fig. 5. Vertical distribution of mean $\Delta \delta^{13} \mathrm{C}$ signatures of macrofaunal taxa with sediment depth $(0-10 \mathrm{~cm})$ at Station M. Bars denote $+1 \mathrm{SD}$

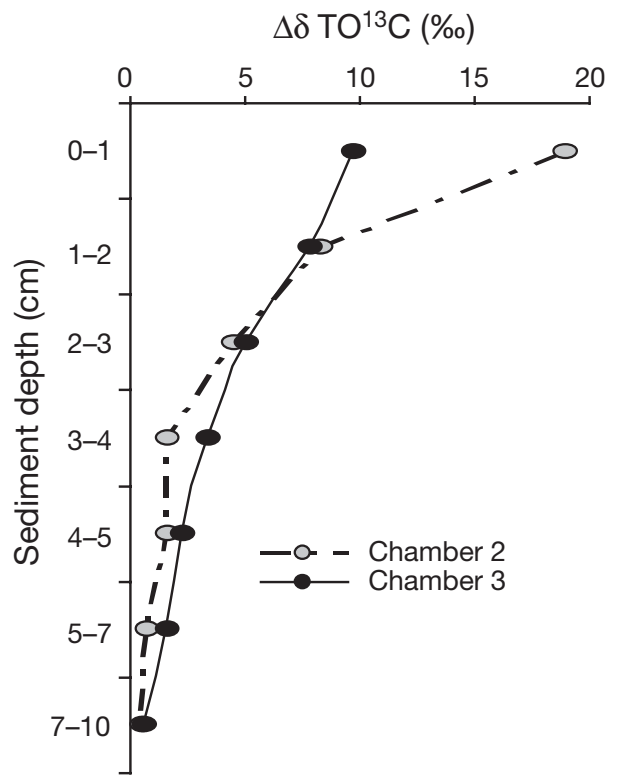

Fig. 6. Specific labelling of total organic (TO) ${ }^{13} \mathrm{C}$ in the sediment $\left(\Delta \delta \mathrm{TO}^{13} \mathrm{C}\right)$ in each replicate experimental chamber

deviations of macrofaunal density and biomass estimates were extremely large suggesting high spatial heterogeneity amongst the macrofaunal community a pattern also noted by Drazen et al. (1998). Like Drazen and his co-workers, we found no significant difference in macrofaunal abundance or biomass in relation to sampling technique (multicorer $\left[78.5 \mathrm{~cm}^{2}\right.$ ] and benthic chamber lander $\left.\left[400 \mathrm{~cm}^{2}\right]\right)$. Processes that drive macrofaunal community spatial structure - such as the presence or absence of biogenic structures (Levin et al. 1986, Schaff \& Levin 1994) - must therefore function at scales different from the area difference enclosed by both sampling devices.

Previous publications point to the dominance of either polychaetes (Schaff \& Levin 1994, Flach \& Heip
1996, Cosson et al. 1997) or crustaceans at deep-sea environments (Drazen et al. 1998, Witte 2000, Aberle \& Witte 2003). In the present study, the crustaceans were the most abundant group (excluding nematodes) and contributed most to overall biomass. However in an earlier investigation at Station M, Drazen et al. (1998) found the polychaetes to contribute more to community biomass, a discrepancy most likely due to the high spatial heterogeneity of macrofauna previously discussed.

As already stated, crustaceans were numerically dominated by the Harpacticoida, but by the Ostracoda in terms of biomass. Drazen et al. (1998) also reported that the Harpacticoida were the most dominant crustacean group in their study, but found the Isopoda to contribute more to overall crustacean biomass. Of the polychaetes sampled, the Paraonidae were most abundant. In a study carried out on the central equatorial Pacific abyssal plain, Glover et al. (2002) reported that the polychaete assemblage was highly dominated by members of the Paraonidae $(\sim 17 \%)$. Paterson et al. (1998) found relatively high densities of paraonid polychaetes (range: 8.5 to $15.2 \%$ ) at 3 sites in the equatorial Pacific and Schaff \& Levin (1994) reported elevated densities of the paraonid Levinsenia gracilis in the vicinity of biogenic structures such as tubes, pits and mounds. Furthermore, in a feeding study conducted on the continental slope off the east coast of the USA, Levin et al. (1999) noted that paraonids were very active sediment and diatom ingesters, leading the authors to postulate that paraonids were opportunistic/ flexible feeders. It is this opportunistic lifestyle that probably allows the paraonids to reach high densities in relation to other polychaetes at the food-limited seafloor of Station $M$.

Lack of accessibility to, and the high costs and risks associated with conducting research in the deep sea means that relatively little is still known about macrofaunal feeding ecology. Very often, inferences on deep-water feeding guilds are drawn based on animal mouth morphologies and/or feeding modes of shallowwater analogues. In recent years the use of natural stable $\mathrm{C}$ and $\mathrm{N}$ isotope measurements and, more recently, the pulse-chase approach, have provided insightful information about macrofaunal feeding ecology and C flow through deep-sea food webs (Fry \& Sherr 1984, Levin et al. 1999, Iken et al. 2001, Aberle \& Witte 2003, Witte et al. 2003a). Natural $\delta^{13} \mathrm{C}$ signatures of the macrofauna at Station M (-19.9 $\pm 2.4 \%$ SD) suggested a dependency on a phytoplankton-based food web (Fry \& Sherr 1984). Natural ${ }^{13}$ C-isotopic signatures measured in the present study were comparable to those measured from 2 bathyal sites located off the Carolina margin by Levin et al. (1999). In comparison to the PAP, where polychaetes and crustaceans 
Table 1. Isotopic signatures and C-turnover of macrofaunal organisms within 2 replicate chambers (Chambers 2 \& 3 ) and their vertical position within the sediment column $(0$ to $10 \mathrm{~cm})$ at Station M. n: number of organisms combined for 1 measurement. Undet.: undetermined. Note: in Chamber 2, a single amphipod from 0 to $2 \mathrm{~cm}$ depth was accidentally combined with an amphipod from 5 to $10 \mathrm{~cm}$ depth prior to isotope ratio mass spectrometry (IRMS) analysis. Since different areas of sediment were sampled from these 2 horizons (see 'Materials and methods'), we were unable to calculate a value for C-turnover per unit area for these 2 pooled animals despite the sample showing a $\delta^{13} \mathrm{C}$ signature of $>-14 \%$

\begin{tabular}{|c|c|c|c|c|c|c|c|}
\hline Taxon & $\begin{array}{l}\text { Sediment } \\
\text { depth }(\mathrm{cm})\end{array}$ & $\begin{array}{l}\text { Biomass } \\
(\mu \mathrm{g} \mathrm{C})\end{array}$ & $\mathrm{n}$ & $\delta^{13} \mathrm{C}(\%)$ & $\Delta \delta^{13} \mathrm{C}(\%)$ & $\begin{array}{c}\text { C-turnover } \\
\left(\times 10^{-3} \mathrm{mg} \mathrm{C} \mathrm{m}^{-2} \mathrm{~d}^{-1}\right)\end{array}$ & $\begin{array}{c}\text { C ingestion } \\
(\% \text { of body wt } C)\end{array}$ \\
\hline \multicolumn{8}{|l|}{ Chamber 2} \\
\hline \multicolumn{8}{|l|}{ Crustacea } \\
\hline Amphipoda & $2-10$ & 10.69 & 2 & 36.71 & 56.83 & $\ldots$ & 0.78 \\
\hline Harpacticoida & $0-2$ & 33.63 & 15 & -20.93 & $\ldots$ & $\ldots$ & $\ldots$ \\
\hline Tanaidacea & $0-2$ & 30.36 & 5 & -20.99 & $\cdots$ & $\ldots$ & $\cdots$ \\
\hline Cumacea & $0-2$ & 11.63 & 1 & 107.07 & 127.20 & 5.94 & 1.75 \\
\hline Cladocera & $5-10$ & 23.56 & 1 & -21.56 & $\ldots$ & $\ldots$ & $\ldots$ \\
\hline Ostracoda & $0-2$ & 4.39 & 1 & -20.57 & $\cdots$ & $\cdots$ & $\cdots$ \\
\hline Ostracoda & $0-2$ & 2.94 & 1 & -12.36 & 5.64 & 0.06 & 0.07 \\
\hline Ostracoda & $0-2$ & 1.83 & 1 & -11.56 & 6.44 & 0.05 & 0.08 \\
\hline Ostracoda & $0-2$ & 2.38 & 1 & -12.03 & 5.97 & 0.05 & 0.08 \\
\hline Ostracoda & $0-2$ & 1.67 & 1 & -5.73 & 12.27 & 0.08 & 0.17 \\
\hline Ostracoda & $2-5$ & 3.03 & 1 & -13.95 & 4.05 & 0.05 & 0.05 \\
\hline Ostracoda & $5-10$ & 2.41 & 1 & -9.55 & 8.45 & 0.09 & 0.11 \\
\hline \multicolumn{8}{|l|}{ Polychaeta } \\
\hline Paraonidae & $0-2$ & 8.47 & 1 & -8.08 & 12.97 & 0.44 & 0.18 \\
\hline Paraonidae & $0-2$ & 35.90 & 1 & -19.29 & $\ldots$ & $\ldots$ & $\ldots$ \\
\hline Phyllodocidae & $0-2$ & 10.18 & 1 & -18.96 & $\ldots$ & $\ldots$ & $\ldots$ \\
\hline Capitellidae & $2-5$ & 2510.37 & 1 & -18.61 & $\ldots$ & $\ldots$ & $\ldots$ \\
\hline \multicolumn{8}{|l|}{ Other metazoa } \\
\hline Bivalvia & $0-2$ & 7.06 & 1 & -15.49 & $\ldots$ & $\ldots$ & $\ldots$ \\
\hline Bivalvia & $0-2$ & 3.12 & 1 & -11.27 & 8.79 & 0.11 & 0.12 \\
\hline Bivalvia & $2-5$ & 8.93 & 1 & -17.98 & $\ldots$ & $\ldots$ & $\ldots$ \\
\hline Bivalvia & $5-10$ & 26.88 & 1 & -17.81 & $\ldots$ & $\ldots$ & $\cdots$ \\
\hline Nematoda & $0-2$ & 14.69 & 1 & -19.28 & $\ldots$ & $\ldots$ & $\ldots$ \\
\hline Nematoda & $0-2$ & 18.07 & 10 & -21.25 & $\ldots$ & $\ldots$ & $\ldots$ \\
\hline Nematoda & $0-2$ & 13.50 & 19 & -20.85 & $\ldots$ & $\ldots$ & $\ldots$ \\
\hline Nematoda & $2-5$ & 23.19 & 8 & -20.03 & $\ldots$ & $\ldots$ & $\ldots$ \\
\hline Nematoda & $2-5$ & 14.23 & 2 & -19.74 & $\ldots$ & $\ldots$ & $\ldots$ \\
\hline Nematoda & $2-5$ & 19.31 & 24 & -22.27 & $\ldots$ & $\ldots$ & $\ldots$ \\
\hline Brachiopoda & $2-5$ & 1.89 & 1 & -2.45 & 19.06 & 0.15 & 0.26 \\
\hline Oligochaeta & $0-2$ & 13.09 & 6 & -21.22 & $\ldots$ & $\ldots$ & $\ldots$ \\
\hline Undet. & $0-2$ & 8.07 & 1 & -20.45 & $\ldots$ & $\ldots$ & $\ldots$ \\
\hline Undet. & $0-2$ & 7.66 & 1 & -20.12 & $\ldots$ & $\ldots$ & $\ldots$ \\
\hline \multicolumn{8}{|l|}{ Chamber 3} \\
\hline \multicolumn{8}{|l|}{ Crustacea } \\
\hline Amphipoda & $0-2$ & 811.42 & 1 & -21.83 & $\ldots$ & $\ldots$ & $\ldots$ \\
\hline Harpacticoida & $0-2$ & 30.84 & 6 & -21.33 & $\ldots$ & $\ldots$ & $\ldots$ \\
\hline Harpacticoida & $0-2$ & 26.30 & 13 & -22.05 & $\ldots$ & $\ldots$ & $\ldots$ \\
\hline Tanaidacea & $0-2$ & 421.25 & 1 & -16.22 & $\ldots$ & $\ldots$ & $\ldots$ \\
\hline Tanaidacea & $0-2$ & 20.15 & 1 & -16.66 & $\ldots$ & $\ldots$ & $\ldots$ \\
\hline Tanaidacea & $0-2$ & 19.57 & 3 & -20.21 & $\ldots$ & $\ldots$ & $\ldots$ \\
\hline Cumacea & $2-5$ & 25.21 & 1 & -11.18 & 8.95 & 0.92 & 0.12 \\
\hline Isopoda & $0-2$ & 22.46 & 1 & -17.02 & $\ldots$ & $\ldots$ & $\ldots$ \\
\hline Isopoda & $0-2$ & 14.16 & 1 & -19.62 & $\ldots$ & $\ldots$ & $\ldots$ \\
\hline Isopoda & $2-5$ & 5.69 & 1 & -22.38 & $\ldots$ & $\ldots$ & $\ldots$ \\
\hline Isopoda & $2-5$ & 11.66 & 1 & 273.75 & 295.19 & 13.84 & 4.06 \\
\hline \multicolumn{8}{|l|}{ Polychaeta } \\
\hline Paraonidae & $0-2$ & 41.85 & 1 & 143.97 & 165.02 & 27.82 & 2.28 \\
\hline Paraonidae & $2-5$ & 79.12 & 1 & -21.07 & $\ldots$ & $\ldots$ & $\ldots$ \\
\hline Paraonidae & $2-5$ & 21.15 & 1 & -19.06 & $\ldots$ & $\ldots$ & $\ldots$ \\
\hline Paraonidae & $5-10$ & 50.43 & 1 & -19.93 & $\ldots$ & $\ldots$ & $\ldots$ \\
\hline Trichobranchidae & $0-2$ & 26.56 & 1 & -19.95 & $\ldots$ & $\ldots$ & $\ldots$ \\
\hline Cirratulidae & $2-5$ & 25.45 & 1 & -20.31 & $\ldots$ & $\ldots$ & $\ldots$ \\
\hline
\end{tabular}


Table 1. (continued)

\begin{tabular}{|c|c|c|c|c|c|c|c|}
\hline Capitellidae & $5-10$ & 47.27 & 1 & -20.05 & $\ldots$ & $\ldots$ & $\ldots$ \\
\hline Capitellidae & $5-10$ & 1522.89 & 1 & -18.72 & $\ldots$ & $\ldots$ & $\ldots$ \\
\hline Undet. & $2-5$ & 14.81 & 1 & -20.38 & $\ldots$ & $\ldots$ & $\ldots$ \\
\hline \multicolumn{8}{|l|}{ Other metazoa } \\
\hline Ophiuroida & $0-2$ & 34.26 & 1 & 20.57 & 42.07 & 5.83 & 0.58 \\
\hline Nematoda & $0-2$ & 52.06 & 8 & -19.40 & $\ldots$ & $\ldots$ & $\ldots$ \\
\hline Nematoda & $0-2$ & 43.58 & 45 & -20.18 & $\ldots$ & $\ldots$ & $\ldots$ \\
\hline Nematoda & $0-2$ & 25.03 & 34 & -22.83 & $\ldots$ & $\ldots$ & $\ldots$ \\
\hline Nematoda & $2-5$ & 63.62 & 1 & -18.50 & $\ldots$ & $\ldots$ & $\ldots$ \\
\hline Nematoda & $2-5$ & 46.36 & 15 & -21.37 & $\ldots$ & $\ldots$ & $\ldots$ \\
\hline Nematoda & $2-5$ & 33.72 & 29 & -17.39 & $\ldots$ & $\ldots$ & $\ldots$ \\
\hline Nematoda & $2-5$ & 24.43 & 39 & -20.68 & $\ldots$ & $\ldots$ & $\ldots$ \\
\hline Nematoda & $2-5$ & 18.04 & 12 & -19.95 & $\ldots$ & $\ldots$ & $\ldots$ \\
\hline Nematoda & $5-10$ & 36.84 & 16 & -19.86 & $\ldots$ & $\ldots$ & $\ldots$ \\
\hline
\end{tabular}

showed average $\delta^{13} \mathrm{C}$ signatures of -25 and $-24 \%$, respectively (Aberle \& Witte 2003), polychaetes and crustaceans from Station $M$ exhibited heavier signatures, suggesting more recent ingestion of a fresh $\mathrm{C}$ source. Aberle \& Witte (2003) conducted their experiments in May/June 2000, before the pulse of exported phytodetritus had settled to the abyssal plain, in contrast to the present investigation, which was carried out in late October 2004, a mere 3 to 4 mo after the peak POM pulse, around the same time as the autumn POM pulse event (Baldwin et al. 1998, Drazen et al. 1998, Smith et al. 2001). Druffel et al. (1998) showed that POC settling at a depth of $3450 \mathrm{~m}$ in the water column at Station $\mathrm{M}$ in September 1994 possessed a $\delta^{13} \mathrm{C}$ signature of $\sim 21 \%$. Thus, if we assume a $\delta^{13} \mathrm{C}$ enrichment of $1 \%$ o per trophic step (Fry \& Sherr 1984), it seems plausible that the heavier signatures measured in our study were the result of fauna assimilating a fresher, more labile food source than those sampled by Aberle \& Witte (2003). This assertion is further supported by the results of Iken et al. (2001), who measured natural $\delta^{13} \mathrm{C}$ signatures in polychaetes and crustaceans at the PAP in September 1996 and July 1997 (immediately after the peak POM pulse) and found lower $\delta^{13} \mathrm{C}$ signatures $(-17.4 \pm 1.4 \%$ and $-17.9 \pm$ $1.2 \%$, respectively). Mean natural $\delta^{13} \mathrm{C}$ and $\delta^{15} \mathrm{~N}$ signatures of deposit feeding and carnivorous polychaetes were surprisingly similar (Fig. 4), despite carnivores generally living at higher trophic levels and thus exhibiting heavier isotopic signatures compared to deposit-feeding animals. Nevertheless, a large degree of variability was evident in $\delta^{13} \mathrm{C}$ signatures of carnivorous polychaetes owing to a very lightly labelled syllid of the genus Brania sp. The majority of the Syllidae have been classified as carnivores by Fauchald \& Jumars (1979) and Gaston (1987), but based on the $\delta^{13} \mathrm{C}$ signature found for Brania sp., we postulate that this particular genus ingests highly refractory detritus, though it may alter its diet, living as a carrion feeder and/or carnivore when the opportunity arises
(Fauchald \& Jumars 1979). Due to the small size of this animal we were unable to measure its $\delta^{15} \mathrm{~N}$ signature and, as such, this statement must remain a postulation until further studies are conducted. Surprisingly, of all the taxa measured for $\delta^{15} \mathrm{~N}$, none appeared to feed directly on sediment and associated phytodetritus, assuming a ${ }^{15} \mathrm{~N}$ enrichment of $3.5 \%$ per trophic level (Fry \& Sherr 1984, Fry 1988) and a sediment-plus-POM $\delta^{15} \mathrm{~N}$ signature of $9 \pm 0.1 \%$, which is in good agreement with previous $\delta^{15} \mathrm{~N}$ signatures for POM (Iken et al. 2001). Rather, the Harpacticoida, Isopoda, Aplacophora, and Ampharetidae appeared to be feeding at the second trophic level $\left(\delta^{15} \mathrm{~N}>12.5 \%\right.$, Fig. $\left.4 \mathrm{a}\right)$ with the remaining polychaetes, nematodes and those unclassified animals feeding at the third trophic level $\left(\delta^{15} \mathrm{~N}>16 \%\right.$, Fig. 4a). Since trichobranchid and paraonid polychaetes have been previously classified as surface and sub-surface deposit feeders, respectively (Fauchald \& Jumars 1979, Gaston 1987, Levin et al. 1997,1999$)$, it is possible that the large $\delta^{15} \mathrm{~N}$ signatures measured for these 2 taxa $\left(\delta^{15} \mathrm{~N}>17 \%\right.$ o) resulted from IRMS sample reproducibility error. Additionally surprising was the extremely large $\delta^{15} \mathrm{~N}$ signature found among opheliid polychaetes analyzed in this study; this suggests a carnivorous, rather than a detritivorous lifestyle, as has been previously proposed in the literature (Fauchald \& Jumars 1979). The opheliid polychaetes sampled may have instead been preying on protozoans (Fauchald \& Jumars 1979).

Remarkably, only a small fraction of the macrofauna sampled from both experimental chambers showed $\delta^{13} \mathrm{C}$ signatures indicative of ${ }^{13} \mathrm{C}$ ingestion. This differs sharply with in situ pulse-chase experiments carried out at the PAP by Aberle \& Witte (2003), who found after only $2.5 \mathrm{~d}$, approximately $77 \%$ of the polychaetes and crustaceans (ca. 95\% of the macrofauna) were already labelled. Vertical $\Delta \delta^{13} \mathrm{C}$ profiles highlighted the relative importance of the top sediment layers $(0$ to $5 \mathrm{~cm}$ ) in abyssal C cycling, and indicated that deeperdwelling macrofauna had far less access to the labelled 
food source than those living within the top $5 \mathrm{~cm}$. These findings concur with earlier investigations carried out in the abyssal NE Atlantic (Aberle \& Witte 2003, Witte et al. 2003a), deep Sognefjord (Witte et al. 2003b) and a shallow shelf habitat (Kamp \& Witte 2005). Jumars et al. (1990) hypothesized that in environments characterized by highly sporadic foodsupply and scarce food resources (e.g. abyssal regions), fauna burrow with food to deeper sediment layers in an effort to store food out of reach of competitors. Despite only a single ostracod from a single chamber showing $\Delta \delta^{13} \mathrm{C}$ values greater than $-14 \%$ at 5 to $10 \mathrm{~cm}$ depth (Table 1), $\Delta \delta \mathrm{TO}^{13} \mathrm{C}$ profiles did reveal the presence of small amounts of labelled material at 7 to $10 \mathrm{~cm}$ depth in both chambers. Although we cannot specifically assign a subduction mechanism for the $\Delta \delta \mathrm{TO}^{13} \mathrm{C}$ profiles observed, it is possible that the presence of capitellid and paraonid polychaetes (Table 1), families known for their burrowing lifestyles (Fauchald \& Jumars 1979), contributed to these distributions. If this is true, faunal-mediated burial of organic matter to deeper sediment layers would provide highly reactive, labile resources to fauna and microbes living beneath the surficial sediments (Levin et al. 1997, Witte et al. 2003b).

As stated before, both specific uptake $\left(\Delta \delta^{13} \mathrm{C}\right)$ and Cturnover rates varied among and within taxa and were almost negligible with the exception of 4 individual organisms. Of the 6 paraonids analysed, 4 showed background isotope signatures indicating no ingestion of our tracer, one had ingested a minor amount, whilst another individual was heavily labelled. In Chamber 2, while ${ }^{13} \mathrm{C}$ uptake was detectable in one third of organisms, only 1 cumacean was heavily labelled and responsible for $85 \%$ of C-uptake. In Chamber 3, a total of 3 individuals were significantly labelled, with the above-mentioned paraonid being responsible for $57 \%$ of C-uptake. This is especially noteworthy when one considers that these animals accounted for only 0.4 and $1.2 \%$ of the total biomass $(\mathrm{C})$, respectively, and had ingested up to $2.3 \%$ of their body weight in $\mathrm{C}$.

Total C-turnover rates for the whole macrofaunal community at Station M were approximately 2 orders of magnitude lower than at the PAP (Witte et al. 2003a) in the NE Atlantic. When normalized to both the amount of $\mathrm{C}$ added and incubation time, the average C-turnover rate at Station $M$ was $1.3 \%$ of that in the NE Atlantic, with $2.3 \times 10^{-3} \%$ of algal $\mathrm{C}$ added being processed at Station M (in $24 \mathrm{~h}$ ) compared to $0.18 \%$ at the PAP. While it is important to bear in mind the highly variable response in this study (total C-turnover by the macrofaunal community varied by an order of magnitude between replicates despite similar overall biomass in both chambers), this is likely due to the different fractions of the macrofauna community that had ingested significant amounts of ${ }^{13} \mathrm{C}$-labelled POM (6.7 vs. $55 \%$ of specimens, representing $1.4 \mathrm{vs.} 97 \%$ of the biomass at Station M and PAP, respectively) and indicates that macrofaunal response patterns to fresh POM may vary seasonally. Witte et al. (2003a) carried out their investigation immediately prior to the maximum POM pulse settlement, whilst our experiments were carried out at approximately the same time as the autumn POM pulse event (Baldwin et al. 1998, Drazen et al. 1998). Also, sedimentary organic C content during the experiment was 4 times higher at Station $\mathrm{M}$ than at PAP (1.7 vs. $0.4 \mathrm{wt} \%$ ). Therefore, an immediate response by the entire macrofaunal community, coupled with elevated C-turnover rates at the PAP, would be a reasonable trait of a severely food-limited community, as opposed to a macrofaunal population that had very recently ingested fresh-bloom C. Had our experiments been carried out at a similar time of year (i.e. immediately prior to the main POM pulse event when the fauna should naturally be more foodstarved), and/or for a similar duration (i.e. 60 instead of 36 h), we may have observed a reaction by the Station M macrofaunal community, both in terms of percentage labelled and macrofaunal C-turnover, that was similar to that measured at the PAP (Aberle \& Witte 2003, Witte et al. 2003a).

Dissimilarities in macrofaunal community structure may also help to explain the different response patterns between Station M and the PAP. Aberle \& Witte (2003) documented that surface deposit-feeding cirratulid polychaetes (1) were the most abundant polychaete family, (2) contributed most to polychaete biomass, and (3) showed some of the highest ${ }^{13} \mathrm{C}$ signals measured. These results allowed the investigators to speculate that this particular family plays a leading role in reworking freshly deposited POM in the NE Atlantic. At Station $\mathrm{M}$ however, the sub-surface deposit-feeding Paraonidae and carnivorous Pilargidae were the most abundant polychaete families found, with the Cirratulidae making up less than $10 \%$ of the population. Members of the Paraonidae and subsurface deposit-feeding Capitellidae also made up the largest fraction of polychaetes in our 2 replicate experiments, making it reasonable to assume that they had far less access to our fresh food source than would surface-deposit feeding polychaetes. Thus, the larger assemblage of sub-surface deposit-feeding polychaetes and the smaller, sometimes absent (Chamber 2), surface deposit-feeding polychaete community in our 2 replicate experiments may additionally explain the comparatively small amount of $\mathrm{C}$ processed at Station M.

All of these findings emphasize the amount of heterogeneity and plasticity in the response to a food pulse on the family, taxon and community levels. 
Reasons for this variability may stem from variations in POM supply and demand (Aspetsberger 2005, Bühring et al. 2006), particle size (Wheatcroft 1992), age (Smith et al. 1993) and density (Mayer et al. 1993), as well as from variations in metabolic state, infaunal life history, the degree of selective ingestion, and assimilation and feeding modes of the taxa (Aberle \& Witte 2003, Fauchald \& Jumars 1979). Finally, our results stress the need for long-term, time-series pulse-chase experiments with multiple replications in order to reliably quantify and identify reasons for temporal and spatial variations in macrofaunal $\mathrm{C}$ cycling at abyssal depths.

Acknowledgements. Our sincerest gratitude goes to K. L. Smith Jr. for inviting us onto his 'PULSE 45' cruise and to him and his team, as well as the captain and crew of the RV 'New Horizon,' for their invaluable assistance during the cruise. We extend our appreciation to J. Langreder, G. Schussler, H. Ruhl, D. Bailey, M. Vardaro, B. Wilson, and J. Ellena for their help with the lander deployments and sample collection. Our thanks go to G. Lavik and M. M. M. Kuypers (MPI), together with D. Harris (UC Davis), for running our IRMS samples. We are deeply grateful to C. R. Smith, N. AberleMalzahn and S. Sommer for helpful discussions concerning the data, and O. Pfannkuche for allowing us to use his laboratory. We are very grateful to L. Lovell for confirming and, in some cases, rejecting initial polychaete identifications and to 3 anonymous reviewers for constructive comments on an earlier version of the manuscript. This research was supported by the Max Planck Gesellschaft and the National Science Foundation (Grant number OCE-02-42472 to K. L. Smith Jr.).

\section{LITERATURE CITED}

Aberle N, Witte U (2003) Deep-sea macrofauna exposed to a stimulated sedimentation event in the abyssal NE Atlantic: in situ pulse-chase experiments using ${ }^{13} \mathrm{C}$-labelled phytodetritus. Mar Ecol Prog Ser 251:37-47

Aspetsberger F (2005) Benthic carbon turnover in continental slope and deep-sea sediments: importance of organic matter quality at different time scales. PhD thesis, University of Bremen

Baldwin RJ, Glatts RC, Smith KL (1998) Particulate matter fluxes into the benthic boundary layer at a long timeseries station in the abyssal NE Pacific: composition and fluxes. Deep-Sea Res II 45:643-665

Beaulieu SE, Smith KL (1998) Phytodetritus entering the benthic boundary layer and aggregated on the sea floor in the abyssal NE Pacific: macro- and microscopic composition. Deep-Sea Res II 45:781-815

Bett BJ, Gabriella Malzone M, Narayanaswamy BE, Wigham BD (2001) Temporal variability in phytodetritus and megabenthic activity at the seabed in the deep Northeast Atlantic. Prog Oceanogr 50:349-368

Billett DSM, Lampitt RS, Rice AL, Mantoura RFC (1983) Seasonal sedimentation of phytoplankton to the deep-sea benthos. Nature 302:520-522

Blair NE, Levin LA, DeMaster DJ, Plaia G (1996) The shortterm fate of fresh algal carbon in continental slope sediments. Limnol Oceanogr 41(6):1208-1219

Blake JA (1994) Vertical distribution of benthic infauna in continental slope sediments off Cape Lookout, North Carolina. Deep-Sea Res II 41(4-6):919-927

Bühring SI, Lampadariou N, Moodley L, Tselepides A, Witte U (2006) Benthic microbial and whole-community responses to different amounts of ${ }^{13} \mathrm{C}$-enriched algae: Insitu experiments in the deep Cretan Sea (Eastern Mediterranean). Limnol Oceanogr 51(1):157-165

Cosson N, Sibuet M, Galéron J (1997) Community structure and spatial heterogeneity of the deep-sea macrofauna at three contrasting stations in the tropical northeast Atlantic. Deep-Sea Res I 44(2):247-269

Deuser WG, Ross EH (1980) Seasonal change in the flux of organic carbon to the deep Sargasso Sea. Nature 283: 364-365

Drazen JC, Baldwin RJ, Smith KL (1998) Sediment community response to a temporally varying food supply at an abyssal station in the NE Pacific. Deep-Sea Res II 45: 893-913

Druffel ERM, Griffin S, Bauer JE, Wolgast DM, Wang XC (1998) Distribution and Particulate Organic Carbon and radiocarbon in the water column from the upper slope to the abyssal NE Pacific Ocean. Deep-Sea Res II 45:667-687

Fauchald K, Jumars PA (1979) The diet of worms: a study of polychaete feeding guilds. Oceanogr Mar Biol Annu Rev 17:193-284

Flach E, Heip C (1996) Vertical distribution of macrozoobenthos within the sediment on the continental slope of the Goban Spur area (NE Atlantic). Mar Ecol Prog Ser 141: $55-66$

Fry B (1988) Food web structure on Georges Bank from stable C, N, and S isotopic compositions. Limnol Oceanogr 33(5): 1182-1190

Fry B, Sherr EB (1984) $\delta^{13} \mathrm{C}$ measurements as indicators of carbon flow in marine and freshwater ecosystems. Contrib Mar Sci 27:13-47

Galéron J, Sibuet M, Vanreusel A, Mackenzie K, Gooday AJ, Dinet A, Wolff GA (2001) Temporal patterns among meiofauna and macrofauna taxa related to changes in sediment geochemistry at an abyssal NE Atlantic site. Prog Oceanogr 50:303-324

Gaston GR (1987) Benthic Polychaeta of the Middle Atlantic Bight: feeding and distribution. Mar Ecol Prog Ser 36: 251-262

Glover AG, Smith CR, Paterson GLJ, Wilson GDF, Hawkins L, Sheader M (2002) Polychaete species diversity in the central Pacific abyss: local and regional patterns, and relationships with productivity. Mar Ecol Prog Ser 240: $157-170$

Gooday AJ (1988) A response by benthic foraminifera to the deposition of phytodetritus in the deep sea. Nature 332: $70-73$

Graf G (1989) Benthic-pelagic coupling in a deep-sea benthic community. Nature 341:437-439

Grasshoff K, Kremling K, Ehrhardt M (1999) Methods of seawater analysis, 3rd edn. John Wiley \& Sons, Hoboken, NJ

Hessler RR, Jumars PA (1974) Abyssal community analysis from replicate box cores in the central North Pacific. Deep-Sea Res I 21:185-209

Holm S (1979) A simple sequential rejective multiple test procedure. Scan J Statistics 6:65-70

Honjo S, Dymond J, Prell W, Ittekkot V (1999) Monsooncontrolled export fluxes to the interior of the Arabian Sea. Deep-Sea Res II 46:1859-1902

Iken K, Brey T, Wand U, Voigt J, Junghans P (2001) Food web structure of the benthic community at the Porcupine Abyssal Plain (NE Atlantic): a stable isotope analysis. Prog Oceanogr 50:383-405 
Jumars PA, Mayer LM, Deming JW, Baross JA, Wheatcroft RA (1990) Deep-sea deposit feeding strategies suggested by environmental and feeding constraints. Philos Trans $\mathrm{R}$ Soc A 331:85-101

Kaehler S, Pakhomov EA (2001) Effects of storage and preservation on the $\delta^{13} \mathrm{C}$ and $\delta^{15} \mathrm{~N}$ signatures of selected marine organisms. Mar Ecol Prog Ser 219:299-304

Kamp A, Witte U (2005) Processing of ${ }^{13} \mathrm{C}$-labelled phytoplankton in a fine-grained sandy-shelf sediment (North Sea): relative importance of different macrofauna species. Mar Ecol Prog Ser 297:61-70

Lampitt RS, Bett BJ, Kiriakoulakis K, Popova EE, Ragueneau O, Vangriesheim A, Wolff GA (2001) Material supply to the abyssal seafloor in the Northeast Atlantic. Prog Oceanogr 50:27-63

Lauerman LML, Smoak JM, Shaw TJ, Moore WS, Smith KL (1997) ${ }^{234} \mathrm{Th}$ and ${ }^{210} \mathrm{~Pb}$ evidence for rapid ingestion of settling particles by mobile epibenthic megafauna in the abyssal NE Pacific. Limnol Oceanogr 42(3):589-595

Levin LA, DeMaster DJ, McCann LD, Thomas CL (1986) Effects of giant protozoans (class: Xenophyophorea) on deep-seamount benthos. Mar Ecol Prog Ser 29:99-104

Levin L, Blair N, DeMaster D, Plaia G, Fornes W, Martin C, Thomas C (1997) Rapid subduction of organic matter by maldanid polychaetes on the North Carolina Slope. J Mar Res 55:595-611

Levin LA, Blair NE, Martin CM, DeMaster DJ, Plaia G, Thomas CJ (1999) Macrofaunal processing of phytodetritus at two sites on the Carolina margin: in situ experiments using ${ }^{13} \mathrm{C}$-labeled diatoms. Mar Ecol Prog Ser 182:37-54

Lochte K, Turley CM (1988) Bacteria and cyanobacteria associated with phytodetritus in the deep-sea. Nature 333: 67-69

Mayer LM, Jumars PA, Taghon GL, Macko SA, Trumbore S (1993) Low-density particles as potential nitrogenous foods for benthos. J Mar Res 51:373-389

Middelburg JJ, Barranguet C, Boschker HTS, Herman PMJ, Moens T, Heip CHR (2000) The fate of intertidal microphytobenthos carbon: an in situ ${ }^{13} \mathrm{C}$-labelling study. Limnol Oceanogr 45(6):1224-1234

Paterson GLJ, Wilson GDF, Cosson N, Lamont PA (1998) Hessler and Jumars (1974) revisited: abyssal polychaete assemblages from the Atlantic and Pacific. Deep-Sea Res II 45:225-251.

Pfannkuche O (1993) Benthic response to the sedimentation of particulate organic matter at the BIOTRANS station, $47^{\circ} \mathrm{N}, 20^{\circ} \mathrm{W}$. Deep-Sea Res II 40(1/2):135-149

Sarakinos HC, Johnson ML, Vander Zanden MJ (2002) A synthesis of tissue preservation effects on carbon and nitrogen stable isotope signatures. Can J Zool/Revue Can Zool 80:381-387

Schaff TR, Levin LA (1994) Spatial structure of benthos

Editorial responsibility: Howard Browman,

Storebø, Norway associated with biogenic structures on the North Carolina continental slope. Deep-Sea Res II 41(4-6):901-918

Smith CR, Pope RH, DeMaster DJ, Magaard L (1993) Agedependent mixing in deep-sea sediments. Geochim Cosmochim Acta 57:1473-1488

Smith KL, Druffel ERM (1998) Long time-series monitoring of an abyssal site in the NE Pacific: an introduction. DeepSea Res II 45:573-586

Smith KL, Kaufmann RS, Baldwin RJ (1994) Coupling of nearbottom pelagic and benthic processes at abyssal depths in the eastern north Pacific Ocean. Limnol Oceanogr 39(5): 1101-1118

Smith KL, Baldwin RJ, Glatts RC, Kaufmann RS, Fisher EC (1998) Detrital aggregates on the seafloor: Chemical composition and aerobic decomposition rates at a time-series station in the abyssal NE Pacific. Deep-Sea Res II 45: $843-880$

Smith KL, Kaufmann RS, Baldwin RJ, Carlucci AF (2001) Pelagic-benthic coupling in the abyssal eastern north Pacific: an 8-year time-series study of food supply and demand. Limnol Oceanogr 46(3):543-556

Smith KL, Baldwin RJ, Ruhl HA, Kahru M, Mitchell BG, Kaufmann RS (2006) Climate effect on food supply to depths greater than $4000 \mathrm{~m}$ in the northeast Pacific. Limnol Oceanogr 51(1):166-176

Venrick EL (1998) Spring in the California Current: the distribution of phytoplankton species, April 1993 and April 1995. Mar Ecol Prog Ser 167:73-88

Waldbusser GG, Marinelli RL, Whitlach RB, Visscher PT (2004) The effects of infaunal biodiversity on biogeochemistry of coastal marine sediments. Limnol Oceanogr 49(5): 1482-1492

Waldbusser GG, Marinelli RL (2006) Macrofaunal modification of porewater advection: role of species function, species interaction, and kinetics. Mar Ecol Prog Ser 311:217-231

Wheatcroft RA (1992) Experimental test for particle sizedependent bioturbation in the deep ocean. Limnol Oceanogr 37(1):90-104

Witte U (2000) Vertical distribution of metazoan macrofauna within the sediment at four sites with contrasting food supply in the deep Arabian Sea. Deep-Sea Res II 47: 2979-2997

Witte U, Pfannkuche O (2000) High rates of benthic carbon remineralisation in the abyssal Arabian Sea. Deep-Sea Res II 47:2785-2804

Witte U, Wenzhöfer F, Sommer S, Boetius A and others (2003a) In situ experimental evidence of the fate of a phytodetritus pulse at the abyssal sea floor. Nature 424:763-765

Witte U, Aberle N, Sand M, Wenzhöfer F (2003b) Rapid response of a deep-sea benthic community to POM enrichment: an in situ experimental study. Mar Ecol Prog Ser 251:27-36

Submitted: May 16, 2007; Accepted: September 5, 2007

Proofs received from author(s): February 6, 2008 